\title{
Taxonomic Note: a Rule about the Deposition of Type Strains
}

\author{
R. G. E. MURRAY \\ Department of Microbiology and Immunology, University of Western Ontario, London, Ontario, Canada N6A 5C1
}

A rule is proposed to replace Recommendation 30a in the International Code of Nomenclature of Bacteria; this rule makes mandatory the deposition of the type strains of cultivable bacterial species and subspecies in a permanent culture collection so that they are available for study.

It was clear during discussions held at the International Congress of Microbiology in Prague, Czech Republic, in July 1994 and reported in the minutes of the Judicial Commission (2) and International Committee on Systematic Bacteriology (3) meetings that it was desirable to have a rule to give force to the intent of Recommendation $30 \mathrm{a}$ and the recommendation appended to Rule 27 in the International Code of Nomenclature of Bacteria (5). These recommendations attempt to encourage but do not enforce the deposition of type strains of validly described and cultivable bacterial species in reliable culture collections which make the strains available to workers who need to study them. The need for more than encouragement is recognized by the editors of the International Journal of Systematic Bacteriology, who insist in their Instructions to Authors (1) that type strains must be deposited in a "recognized culture collection" and that accession numbers must be provided as a requirement for publication. There is a general agreement that access to type strains is essential for making valid comparisons and identifications, and type strains are required to provide a stable basis for both taxonomic assessments and phylogenetic lineages.

It was recognized in the discussions mentioned above that access can be problematic when an application for a patent involves the type strain because publication and distribution while a patent is pending threaten the issuance of the patent. It was clear that names should not be validated until the type strains are available for study. The issues surrounding this problem have now been aired by Labeda et al. (4), who recommend clearly that a description of a new species with a designated type strain subject to a patent application must not be published until the patent is awarded and the culture becomes available from a recognized culture collection. Thus, there is support for the similar requirement promulgated by the editors of this journal (1).

Accordingly, it is proposed that the Judicial Commission and the International Committee on Systematic Bacteriology consider emending the International Code of Nomenclature of Bacteria (5) by deleting Recommendation $30 \mathrm{a}$, adding a third condition and a fourth condition to Rule 30 , and emending the recommendation and reference to Rule 30 in Rule 27 . The following wording of emended Rule 30 is suggested:

Rule 30

For the name of a species to be validly published, it must conform with the following conditions.

(1) It must be published in conformity with Rules 27 and $28 \mathrm{~b}$.

(2) It must be published as a binary combination consisting of a generic name followed by a single specific epithet (see Rule 12a).

(3) The description must include the designation of a type strain, and, if the bacterium is cultivable, a living culture of that strain must be deposited in at least one of the permanently established culture collections, from which subcultures would be available. The designation(s) allotted to the strain by the culture collection(s) must be quoted in the published description. If the species is noncultivable but describable, then type material of a recognizable form must be deposited and/or a photograph or an illustration must be included with the description.

(4) Patented bacteria may serve as type strains and must also be deposited, as in (3) above, but if a patent is not yet awarded or not yet laid open, the publication of a name and a description must be deferred until the patent is awarded and subcultures can be made available.

\section{REFERENCES}

1. Anonymous. 1996. Instructions to authors. Int. J. Syst. Bacteriol. 46:i-xi.

2. Frederiksen, W. 1995. Judicial Commission of the International Committee on Systematic Bacteriology minutes of the meetings, 2 and 6 July 1994, Prague, Czech Republic. Int. J. Syst. Bacteriol. 45:195-196.

3. Goodfellow, M. 1995. International Committee on Systematic Bacteriology minutes of the meetings, 2, 3, and 5 July 1994, Prague, Czech Republic. Int. J. Syst. Bacteriol. 45:613-615.

4. Labeda, D. P., C. P. Kurtzman, and J. L. Swezey. 1995. Taxonomic note: use of patent strains as type strains in the valid description of new microbial taxa. Int. J. Syst. Bacteriol. 45:868-869.

5. Sneath, P. H. A. (ed.). 1992. International code of nomenclature of bacteria: bacteriological code. 1990 revision. American Society for Microbiology, Washington, D.C. 